Article

\title{
Isolation of Antimicrobial Genes from \\ Oryza rufipogon Griff by Using a Bacillus subtilis Expression System with Potential Antimicrobial Activities
}

\author{
Jiale Li, Samiul Islam $₫$, Pengfei Guo, Xiaoqing Hu and Wubei Dong * \\ Department of Plant Pathology, College of Plant Science and Technology and the Key Lab of Crop Disease \\ Monitoring \& Safety Control in Hubei Province, Huazhong Agricultural University, Wuhan 430070, China; \\ lj10410@webmail.hzau.edu.cn (J.L.); samiulislam@webmail.hzau.edu.cn (S.I.); GPF@webmail.hzau.edu.cn (P.G.); \\ hxq123@webmail.hzau.edu.cn (X.H.) \\ * Correspondence: dwb@mail.hzau.edu.cn; Tel.: +86-150-0710-9436
}

Received: 19 September 2020; Accepted: 16 November 2020; Published: 18 November 2020

check for updates

\begin{abstract}
Antimicrobial genes are distributed in all forms of life and provide a primary defensive shield due to their unique broad-spectrum resistance activities. To better isolate these genes, we used the Bacillus subtilis expression system as the host cells to build Oryza rufipogon Griff cDNA libraries and screen potential candidate genes from the library at higher flux using built-in indicator bacteria. We observed that the antimicrobial peptides OrR214 and OrR935 have strong antimicrobial activity against a variety of Gram-positive and Gram-negative bacteria, as well as several fungal pathogens. Owing to their high thermal and enzymatic stabilities, these two peptides can also be used as field biocontrol agents. Furthermore, we also found that the peptide OrR214 (MIC 7.7-10.7 $\mu \mathrm{M}$ ) can strongly inhibit bacterial growth compared to polymyxin B (MIC 5-25 $\mu \mathrm{M}$ ) and OrR935 (MIC 33-44 $\mu \mathrm{M}$ ). The cell flow analysis, reactive oxygen burst, and electron microscopy (scanning and transmission electron microscopy) observations showed that the cell membranes were targeted by peptides OrR214 and OrR935, which revealed the mode of action of bacteriostasis. Moreover, the hemolytic activity, toxicity, and salt sensitivity experiments demonstrated that these two peptides might have the potential to be used for clinical applications. Overall, OrR214 and OrR935 antimicrobial peptides have a high-throughput bacteriostatic activity that acts as a new form of antimicrobial agent and can be used as a raw material in the field of drug development.
\end{abstract}

Keywords: antimicrobial peptides; Bacillus subtilis; wild rice; antimicrobial potentiality; membrane permeability

\section{Introduction}

The effects of resistance to antibiotics are extremely severe and may have a substantial impact on incidence and death, leading to higher economic costs for healthcare systems. Unfortunately, the development and rapid use of antibiotics have led to the gradual emergence of antibiotic-resistant strains. Therefore, an increasing number of infections are caused by microorganisms that do not respond to traditional drugs [1]. However, with the discovery of antibiotics in the twentieth century, healthcare professionals assumed that the battle with microbes was promising, but due to the emergence of a large number of antibiotic-resistant microbes, the fight intensified [2-4]. Hence, it is required to develop alternative antimicrobials or active compounds that offer promising therapeutic substitutes in multiple diseases related to plants, animals, and humans [5,6]. Antimicrobial genes are commonly used in agriculture because they can enhance resistance to plant diseases and also play an important role in 
improving crop variety [7]. Some recent studies have shown that antimicrobial peptides (AMPs) such as AtR472 derived from Aegilops tauschii Cosson, the cationic antimicrobial gene HCAP-18 expressed in Chinese cabbage, and peptide SM-985 from Teosinte (Zea mays ssp. mexicana) have significant inhibitory effects on many plant pathogenic bacteria [8-10]. Besides, antimicrobial peptides have also been used in many fields because of their excellent bacteriostatic effects [11-14]. In some cases, they showed anti-inflammatory and other host-defense features $[15,16]$.

AMPs are typically produced when challenged by microorganisms and play an essential role in the innate immune system [17-19]. As an important part of the innate immune system, AMPs are recognized as the first defense system against the invasion of foreign pathogens by animals, plants and some other organisms [16,20-22]. AMPs are small oligopeptides encoded by genes (less than 100 amino acids) and often contain $\alpha$ helix or $\beta$ sheet folding structures. They have demonstrated activities against several fungal and bacterial pathogens and even some viruses [20-25]. In addition, AMPs have the following features: broad antibacterial spectrum, fast ability to destroy germs, minimal bactericidal concentration, the capacity to be used alone or in combination, and lower side effects [15].

These outstanding features have encouraged researchers to develop techniques to isolate and purify new classes of AMPs and their derivatives from different species [26,27]. Most of the conventional methods of gene screening are focused on genetic homology, which is not an appropriate methodology for acquiring new genes [28]. Therefore, researchers are actively trying to find a new screening method that is more conducive to isolating AMPs. At present, the construction of prokaryotic and eukaryotic expression systems is gradually improving $[29,30]$. However, in the current state of development, the most commonly used expression system is the Escherichia coli (prokaryotic) expression system [31,32]. To secrete peptides into the extracellular space, the emerging Bacillus subtilis system can rely on its high-efficiency secretory expression. It also has a relatively perfect pathogen-free mechanism of action and is more suitable for the large-scale development of antimicrobial genes [27,33].

Rice is the main food crop in many countries around the world. There are two kinds of cultivated rice, Asian and African cultivated rice [34,35]. However, due to artificially overtargeted selection, rice has lost its fundamental resistance genes in the process of acclimation. To improve the resistance of cultivated rice, researchers are more inclined to screen resistant genes from wild-type rice [36,37]. The Zhangpu wild rice (the original ancestor of cultivated rice), which was discovered in Fujian, similar to other common wild rice, has many potential resistance genes, including resistance to disease, insects and heat [38]. At present, researchers have isolated many disease resistance genes from wild rice, and more than 20 resistance genes against rice blast have been cloned, such as Pi9, Pi21, and Pi54, along with genes that confer resistance to xanthophyte, such as Xa21, Xa23, and Xa27 [39-42].

In our lab, using a B. subtilis expression system, we introduced a new method for isolating resistance genes $[27,43]$. This approach is efficient against 'superbug' bacteria and different plant microorganisms for antimicrobial gene isolation. We used this technique in this research and identified resistance genes from O. rufipogon. In addition, the working mechanism of our isolated AMPs on pathogenic microorganisms was also preliminarily clarified, providing a theoretical basis for the subsequent analysis of the action of $O$. rufipogon resistance genes. Finally, this study also demonstrated the effectiveness of these AMPs in controlling plant pathogens.

\section{Results}

\subsection{Screening of Antimicrobial Genes from O. Rufipogon cDNA Libraries by the B. subtilis System}

cDNA libraries were developed using the B. subtilis expression system to identify AMPs from O. rufipogon due to its highly effective expression ability. Considering the initial library titer, the libraries were tested, and the rate of recombination was $1.1 \times 10^{7} \mathrm{CFU} / \mathrm{mL}$ (colony-forming units per milliliter) (Figure S1). Initially, we screened 38 monoclonal clones from a total of 3114 transformants, and phenotypic abnormalities (autolysis) were seen repeatedly. Among them, six clones exhibited strong antimicrobial properties that caused serious damage to host cells (abnormal morphology) with 
substantial changes in cell structure (Figure 1) due to the expression of O. rufipogon foreign resistance genes. Interestingly, these resistance genes not only caused B. subtilis cell damage but also changed their growth pattern to sparse and massive colonies compared with those without autolysis (Figures 1 and 2A). These results indicate that the peptide encoded by the inserted gene is toxic to the host cell, leading to the development of autolysis with a diffusion growth pattern. After BLAST searches in the NCBI database, we found that OrR214 and OrR935 were new peptides (Table S4). For further study based on this screening, the OrR214 and OrR935 genes were chosen.

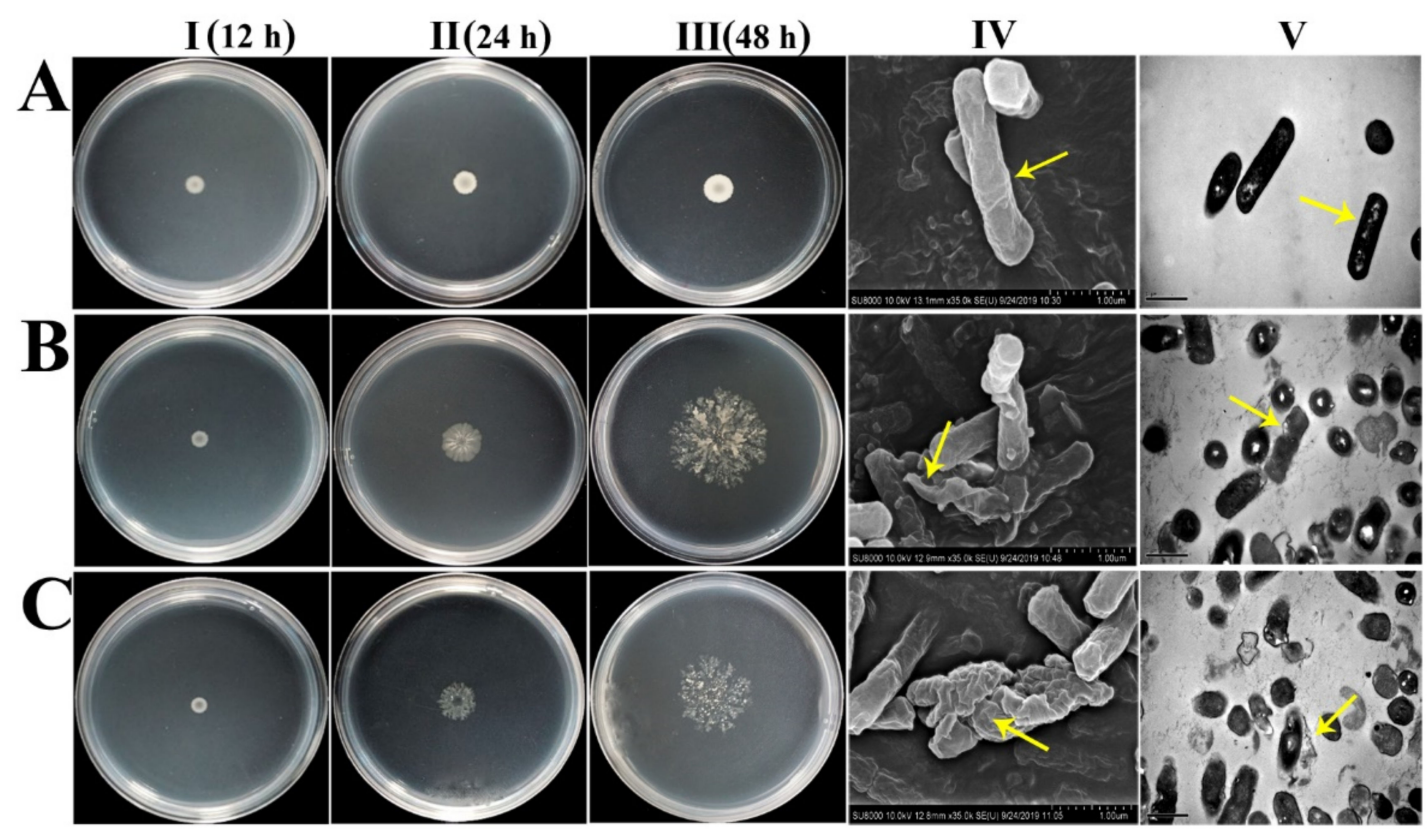

Figure 1. The harmful impacts of antimicrobial gene expression on host cells of $B$. subtilis. The autolytic strains (OrR214 and OrR935) were placed on Luria-Bertani (LB) plates within 12 to $48 \mathrm{~h}$ with the B. subtilis SCK6-e strain and then incubated at $37^{\circ} \mathrm{C}$ to observe the morphological changes. (A-I) B. subtilis SCK6-e strain, (B-I) OrR935 and (C-I) OrR214 grew normally within $12 \mathrm{~h}$, and (A-II) B. subtilis SCK6-e strain, (B-II) OrR935, and (C-II) OrR214 grew after $24 \mathrm{~h}$ of incubation, while (A-III) B. subtilis SCK6-e strain, (B-III) OrR935, and (C-III) OrR214 grew after $48 \mathrm{~h}$ of incubation. (B) (OrR935) and (C) (OrR214) show obvious autolysis and outward diffusion. The samples were freeze-dried with glutaraldehyde and then coated with gold, and (A-IV) B. subtilis SCK6-e strain, (B-IV) OrR935, and (C-IV) OrR214 were examined under a scanning electron microscope, and (A-V) B. subtilis SCK6-e strain, (B-V) OrR935, and (C-V) (OrR214) were examined under a transmission electron microscope. As a control, the B. subtilis empty vector strain (SCK6-e) was used. The scale bar represents $1 \mu \mathrm{m}$. 

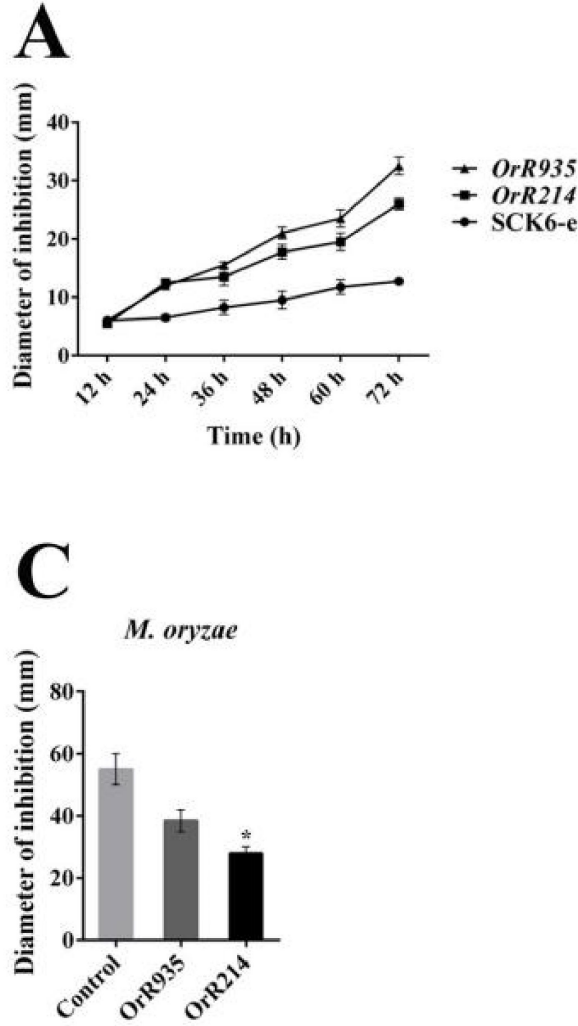

Treatments

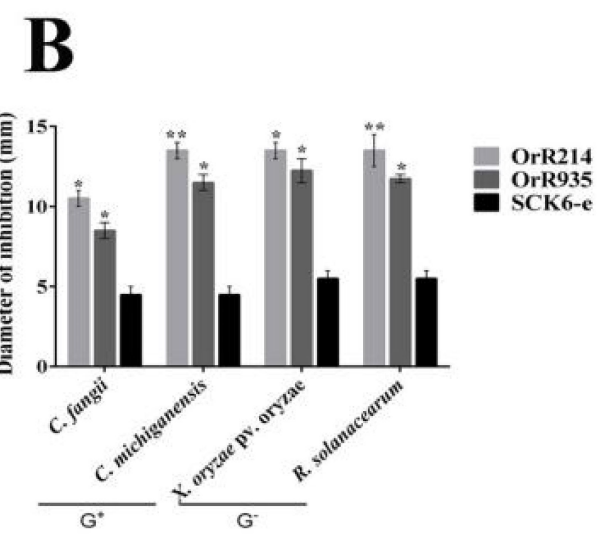

D

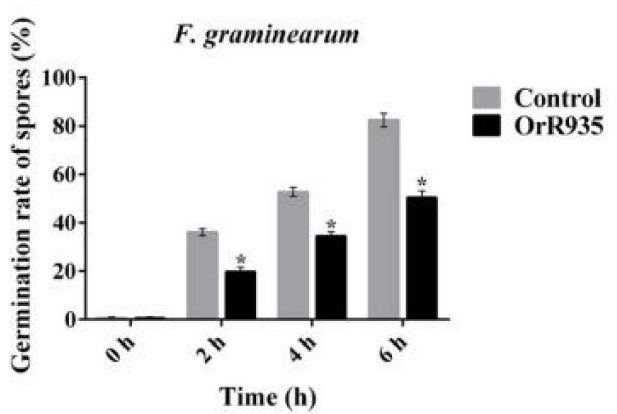

Figure 2. Analysis of antimicrobial potentiality of two resistance genes against pathogens. The B. subtilis SCK6-e strain was employed as a control in this assay. (A) Growth and diffusion diameter of autolytic strains. (B) Both groups of bacterial inhibition compared with SCK6-e in response to peptides OrR214 and OrR935. (C) Inhibition of OrR214 and OrR935 peptides against M. oryzae compared to buffer. (D) Inhibition of the germination rate of OrR935 peptides against spores of F. graminearum compared to buffer. Three individual experimental data points were collected for the mean values. SD (standard deviation) is represented by vertical bars. $T$-tests were carried out to evaluate the significance levels at * $p \leq 0.05$ and $^{* *} p \leq 0.01$.

\subsection{Antimicrobial Activity of Resistance Genes against Pathogenic and Non-Pathogenic Bacteria}

The extracellular antimicrobial features were examined against Gram-positive and Gram-negative bacteria (Clavibacter fangii, Xanthomonas oryzae pv. oryzae, Clavibacter michiganensis subsp, and Ralstonia solanacearum) compared to the control SCK6-e strain (Table S3). The peptides OrR214 and OrR935 had substantial inhibition rates (Figure 2B). In addition, the biological activities against fungal pathogens were also measured (Figures S2 and S3). Among them, the OrR214 peptide could significantly inhibit the mycelium growth of Magnaporthe oryzae (Figure 2C), whereas the OrR935 peptide could inhibit the spore germination of Fusarium graminearum (Figure 2D).

\subsection{Stabilities of Antimicrobial Peptides Influenced by Temperature and Enzymes}

The peptides were heated for $30 \mathrm{~min}$ at $4{ }^{\circ} \mathrm{C}, 50^{\circ} \mathrm{C}, 80^{\circ} \mathrm{C}$ and $100{ }^{\circ} \mathrm{C}$ to determine the stability of the antimicrobial activities. The results from the experiment showed that peptides OrR214 and OrR935 displayed significant activity against Gram-positive and Gram-negative bacteria at 4 to $100^{\circ} \mathrm{C}$ temperature ranges compared to the control (Figure 3). After that, when tested for its sensitivity to enzymes, the results showed that the OrR214 and OrR935 peptides still have notable activity under the action of all proteases but decreased slightly after treatment with peptidase $\mathrm{K}$ and protease $\mathrm{E}$ compared to controls SCK6-e (Figure 4). The activities of the antimicrobial peptides OrR214 and OrR935 were also tested on disease-infected detached rice leaves under in vitro conditions at $7 \mathrm{~d}$. Compared with 
the control groups (Figure 5A), two antimicrobial peptides, OrR935 and OrR214, decreased necrotic leaf lesion growth simultaneously (Figure 5B,C). The effects of two kinds of antimicrobial peptides on $X$. oryzae pv. oryzae are displayed in Figure 5D; the results showed that the incidence of rice leaves treated with antimicrobial peptides OrR214 and OrR935 decreased significantly.
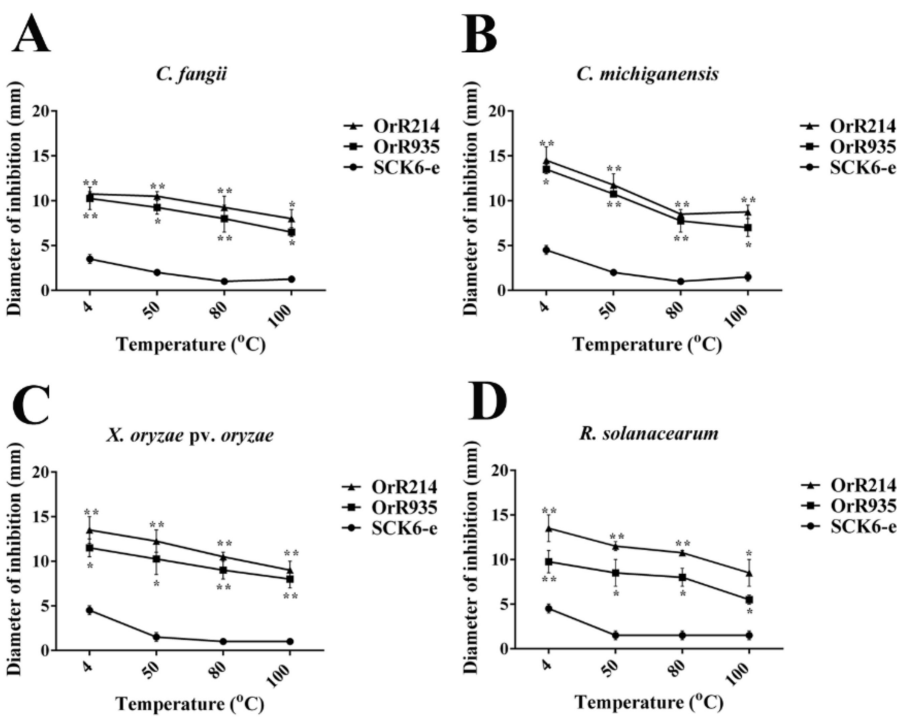

Figure 3. Stabilities of the antimicrobial peptides. Bacteriostatic maps of four indicator bacteria (C. fangii, $X$. oryzae pv. oryzae, C. michiganensis, and $R$. solanacearum) on the plate at different temperatures. (A) (C. fangii), (B) (C. michiganensis), (C) (X. oryzae pv. oryzae), and (D) (R. solanacearum) are graphs of the bacteriostatic diameters of two peptides at various temperatures $\left(4{ }^{\circ} \mathrm{C}, 50{ }^{\circ} \mathrm{C}, 80^{\circ} \mathrm{C}\right.$, and $\left.100{ }^{\circ} \mathrm{C}\right)$. Three individual experimental data points were collected for the mean values. SD is represented by vertical bars. T-tests were conducted for significance analysis at ${ }^{*} p 0.05$ and ${ }^{* *} p \leq 0.01$.
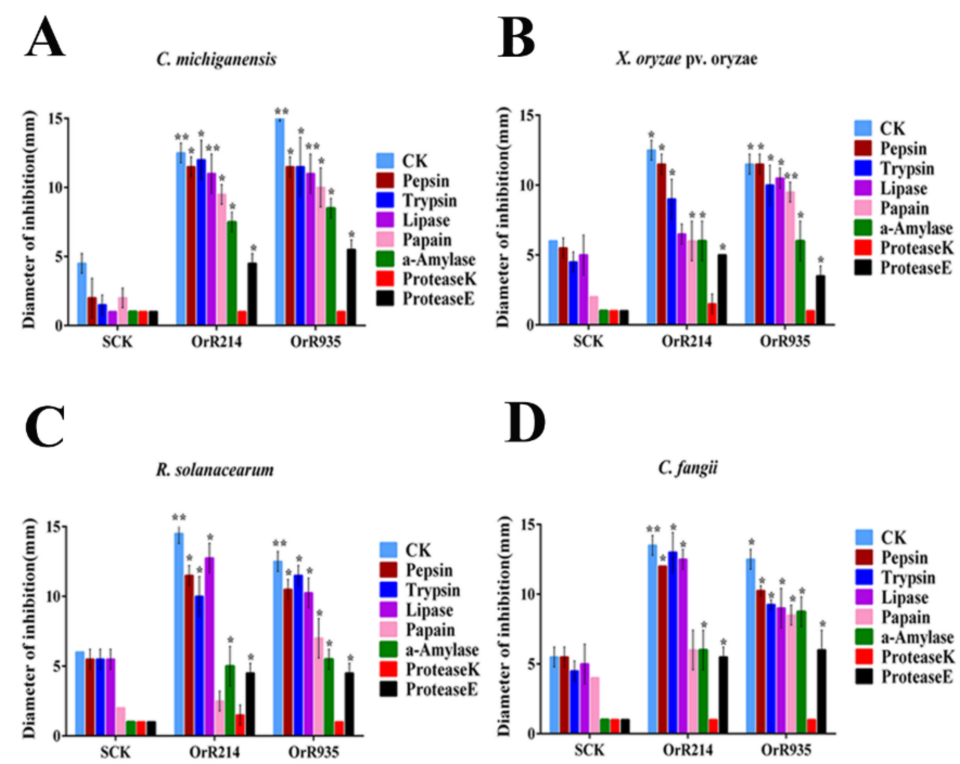

Figure 4. Stability tests of antimicrobial peptides. Inactivation of the antimicrobial activity of two peptides, OrR214 and OrR935, was tested by different biological enzymes. The SCK6-e B. subtilis strain was used as a control, and stabilities were tested against four indicator bacteria. (A) (C. michiganensis), (B) (X. oryzae pv. oryzae), (C) (R. solanacearum), and (D) (C. fangii) represent treatments with seven different kinds of biological enzymes, including pepsin, trypsin, lipase, papain, $\alpha$-amylase, peptidase $\mathrm{K}$, and protease $\mathrm{E}$. The data represent the average of three separate experiments. $T$-tests were conducted for significance analysis at ${ }^{*} p \leq 0.05$ and ${ }^{* *} p \leq 0.01$. 


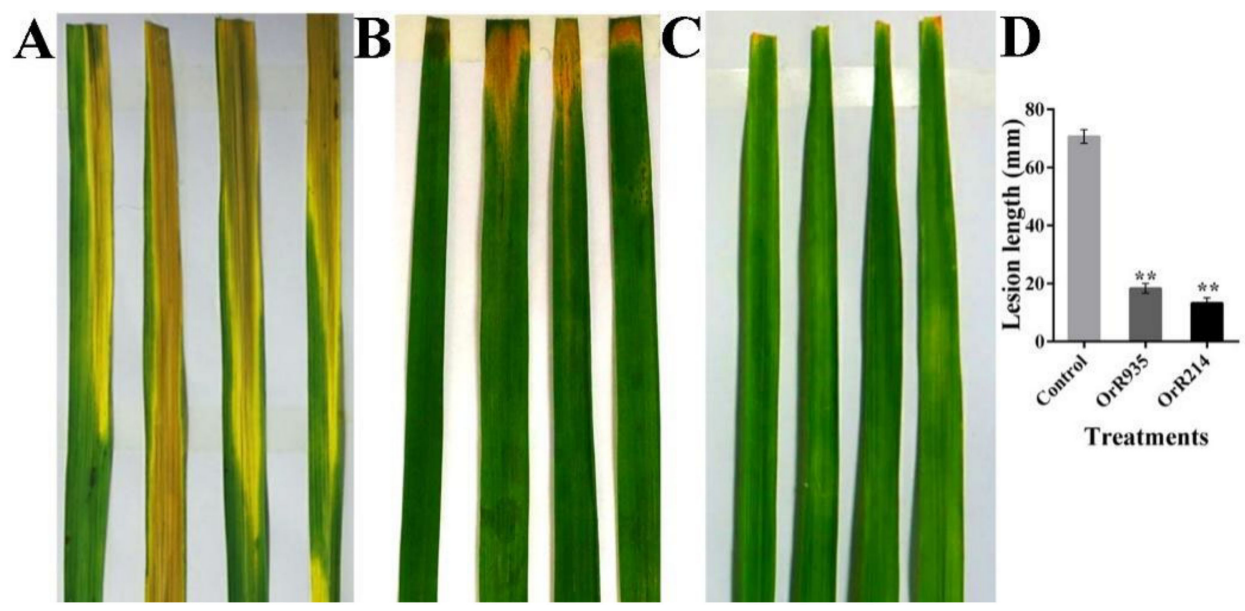

Figure 5. Resistance of rice leaves (X. oryzae pv. oryzae) treated with antimicrobial peptides. The picture shows symptoms of disease on leaves after $7 \mathrm{~d}$ of inoculation. (A) B. subtilis SCK6-e (Control), (B) OrR935, (C) OrR214, and (D) the data lesion length of two peptides OrR935 and OrR214 on rice leaves at $7 \mathrm{~d}$ post-inoculation. For the mean values, three individual experimental data points were collected. The vertical bars reflect SD, and the data were analyzed GraphPad Prism 6 software. T-tests were conducted for significance analysis at ${ }^{* *} p \leq 0.01$.

\subsection{SDS-PAGE Analysis Revealed the Peptide Expression and Sizes of OrR214 and OrR935 and Minimum} Inhibitory Concentration (MIC) Assay

In B. subtilis SCK6, the His-tagged and TEV fusion peptides OrR214 and OrR935 were observed, and then the length of the extracellular peptides was filtered and checked by SDS-PAGE. The molecular weights of OrR214 (approximately $3.3 \mathrm{kDa}$ ) and OrR935 (approximately $2.3 \mathrm{kDa}$ ) were verified from the gel (Figure S4), and we found that the observed size was similar to the predicted size. Using the minimum dilution method, the minimum inhibitory concentration (MIC) values of OrR214 and OrR935 peptides were determined after purification against Gram-negative and Gram-positive bacteria (C. fangii, R. solanacearum, C. michiganensis, X. oryzae pv oryzae, X. oryzae pv. oryzicola, and B. subtilis (168)). The results revealed that the peptide OrR935 (MIC 31.4-44.0 $\mu \mathrm{M}$ ) had lower antibacterial activity. In comparison, the antimicrobial potential of the OrR214 (MIC 7.7-10.7 $\mu \mathrm{M}$ ) peptide against both types of bacteria was substantially higher than that of polymyxin B (MIC 5.0-25.0 $\mu \mathrm{M})$ (Table 1).

Table 1. MIC values $(\mu \mathrm{M})$ of OrR214 and OrR935 peptides against various Gram-positive and Gram-negative bacteria.

\begin{tabular}{cccc}
\hline \multirow{2}{*}{ Strain } & \multicolumn{3}{c}{ MIC $(\boldsymbol{\mu M})$} \\
\cline { 2 - 4 } & Polymyxin B & OrR214 & OrR935 \\
\hline C. fangi & 25.0 & 10.7 & 37.7 \\
C. michiganensis & 12.5 & 10.5 & 34.6 \\
X. oryzae pv. oryzae & 5.0 & 10.1 & 44.0 \\
R. solanacearum & 7.5 & 8.1 & 33 \\
X. oryzae pv. oryzicola & 10.0 & 7.7 & 31.4 \\
B. subtilis (168) & 15.0 & 8.3 & 36.1 \\
\hline
\end{tabular}

Note. Gram-positive bacteria: C. fangii, C. michiganensis, B. subtilis (168). Gram-negative bacteria: R. solanacearum, $X$. oryzae pv. oryzae, X. oryzae pv. oryzicola. Polymyxin B was used as a positive control.

\subsection{Time-Kill Curve Analysis}

The killing abilities of peptides OrR214 and OrR935 on bacterial cells was further studied by analyzing the growth of different Gram-positive and Gram-negative bacteria after peptide treatment at MICs. The results indicated that compared with polymyxin B (MIC $5.0 \mu \mathrm{M})$, with better bactericidal 
efficacy, X. oryzae pv. oryzae treated with the antibacterial peptide OrR214 (MIC $10.1 \mu \mathrm{M})$ hardly grew after $12 \mathrm{~h}$ of treatment (Figure 6). In contrast, the OrR935 peptide (MIC $44.0 \mu \mathrm{M}$ ) showed lower bacteriostatic activity against $X$. oryzae pv. oryzae. Time kill kinetics of $X$. oryzae pv. oryzicola, and R. solanacearum are shown in Supplementary Figure S5.

\section{$X$. oryzae pv. oryzae}

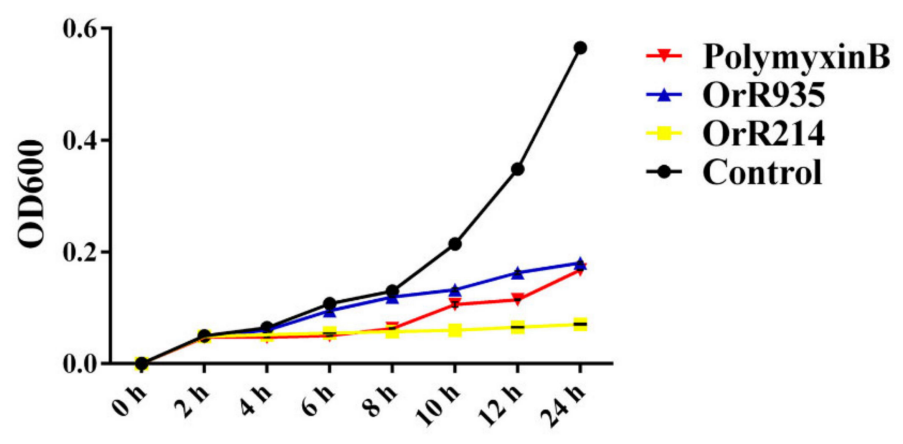

Time (h)

Figure 6. Time-Kill curve. The bacterial growth curve confirmed the inhibitory effects of the antimicrobial peptides OrR214 and OrR935. Time kill kinetics of X. oryzae pv. oryzae by antimicrobial peptides OrR214, OrR935, and Polymyxin B at their MICs. Three individual experimental data points were collected for the mean values.

\subsection{Assay of Hemolytic Activity of Antimicrobial Peptides Against Mammalian Cells}

The potential toxicities of two different antimicrobial peptides were then examined in a hemolytic activity assay. The hemolytic activity results revealed that peptides OrR214 and OrR935 had $0.142 \%$ and $0.306 \%$ hemolytic activity at a concentration of $3 \times$ MICs (Figure 7 ). We observed similar cell survival rates (data not shown) when using higher peptide concentrations (up to $150 \mu \mathrm{M}$ ). To conclude, these two peptides were determined to be relatively safe for mammalian cells in circumstances that resemble the use of human medicines.

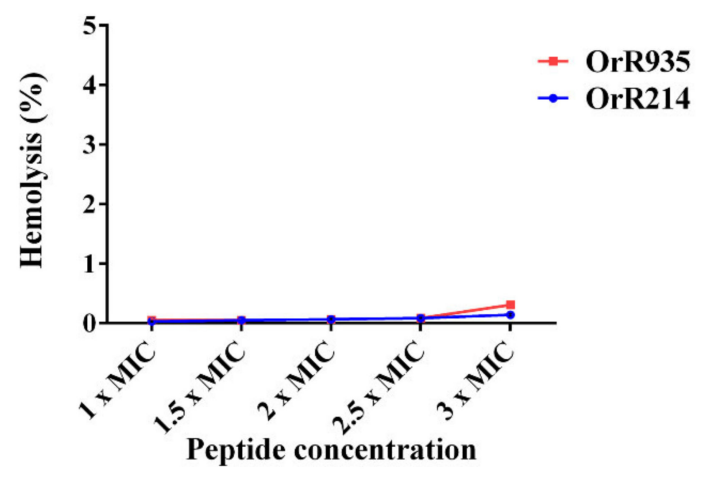

Figure 7. Hemolytic activity curves of the peptides on porcine erythrocytes. The release of hemoglobin was monitored at $385 \mathrm{~nm}$ by measuring the absorbance using a microplate reader.

\subsection{Salt Sensitivity Assay of the Antimicrobial Peptides OrR214 and OrR935}

It has been reported that cations in salt solutions have a particular influence on antimicrobial peptides. For this reason, we studied the effect of cations on the peptides OrR214 and OrR935 (Figure 8A,B), and the results showed that these two AMPs had no antibacterial effect against $C$. fangii in $\mathrm{K}^{+}, \mathrm{Ca}^{2+}$, and $\mathrm{Mg}^{2+}$ salt solutions, while the antibacterial activity against $X$. oryzae pv. oryzae was slightly inhibited. At the $50-100 \mathrm{mM} \mathrm{Na}^{+}$concentration, these two peptides still had a significant bacteriostatic effect on the $C$. fangii and $X$. oryzae pv. oryzae. In contrast, in the presence of $150 \mathrm{mM} \mathrm{Na}^{+}$ 
concentration, the antimicrobial activities of these two peptides on C. fangii and X. oryzae pv. oryzae were slightly affected.
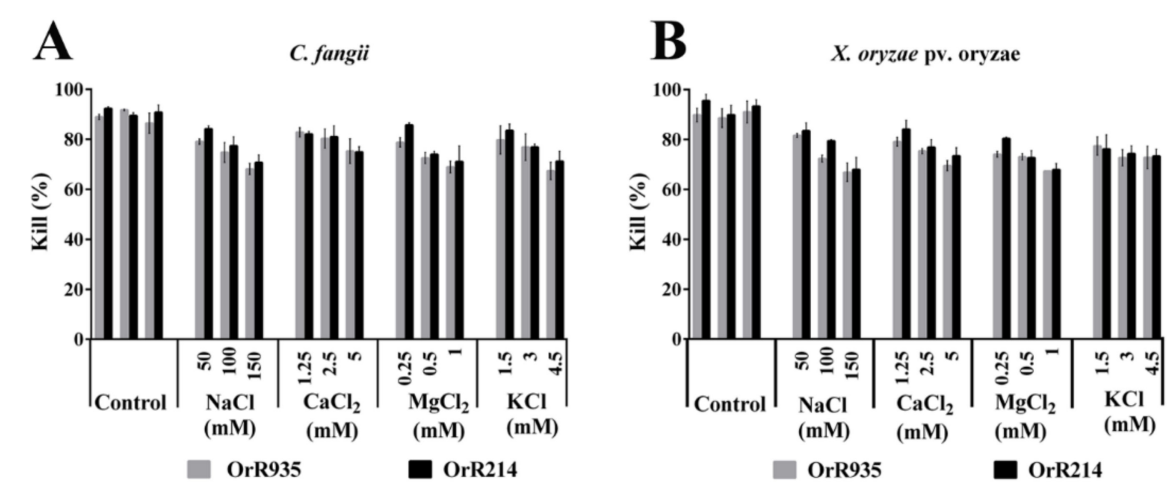

Figure 8. The effects of antimicrobial peptides under various cationic concentrations against the indicator bacteria X. oryzae pv. oryzae (A) and (B) C. fangii. The control contained no salt. Three individual experimental data points were collected for the mean values.

\subsection{Antimicrobial Peptides OrR214 and OrR935 Induce Reactive Oxygen Species (ROS) Production}

Antimicrobial peptides may cause a microbial reactive oxygen burst in the process of inhibiting pathogenic microorganisms, which is generally considered to be one of the mechanisms of antimicrobial peptides. The 2,7-dichlorodihydrofluorescein (DCFH) produced by 2,7-dichlorodihydrofluorescein diacetate (DCFH-DA) hydrolysis in cells can be oxidized by reactive oxygen species to produce green fluorescence. To detect the production of Reactive Oxygen Species (ROS) by the antimicrobial peptides OrR214 and OrR935, DCFH-DA was oxidized by reactive oxygen species to produce green fluorescence under a fluorescence microscope, and then the ROS levels were determined. The results are shown under the MIC conditions where two antimicrobial peptides and bacterial cells were incubated for $30 \mathrm{~min}$. After that, the fluorescence intensity was significantly increased and still showed an upward trend at 120 min compared to the untreated strain (Figure S6).

\subsection{Effects of OrR214 and OrR935 Peptides on Cell Membrane Permeability}

To further explore the effects of OrR214 and OrR935 peptides on cell membrane integrity, propidium iodide (PI) staining was performed. PI is a nucleic acid dye that enters through a disrupted cell membrane and stains upon binding to a double-stranded nucleic acid. Dot plot analysis showed that the staining rate was significantly increased after treatment with the antimicrobial peptides OrR214 and OrR935, approximately 23.9\% for OrR935 (Figure 9B) and 37.1\% for OrR214 (Figure 9C), and the control was $0.07 \%$ (Figure 9A). These results suggested that peptides OrR214 and OrR935 disrupted the cell membrane integrity of the bacterial cells, and the damage to the cell membrane increased with a higher peptide concentration. 
A

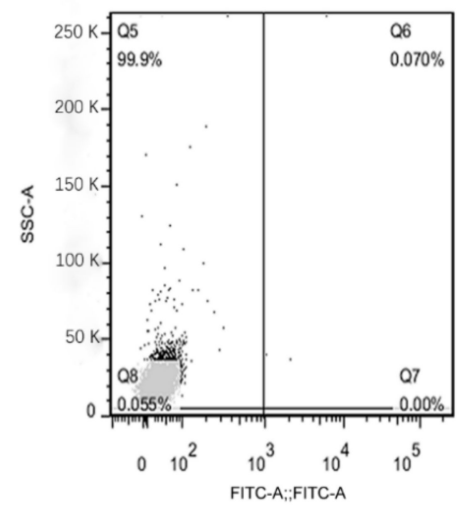

B

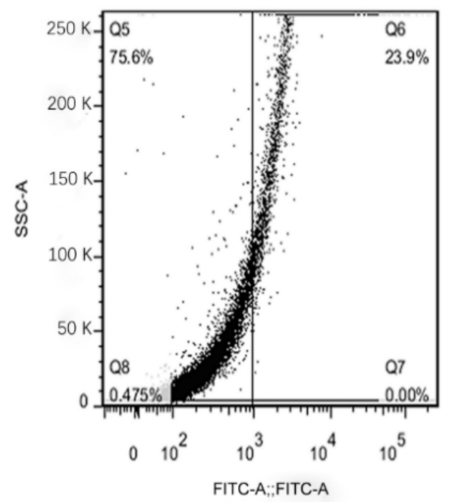

C

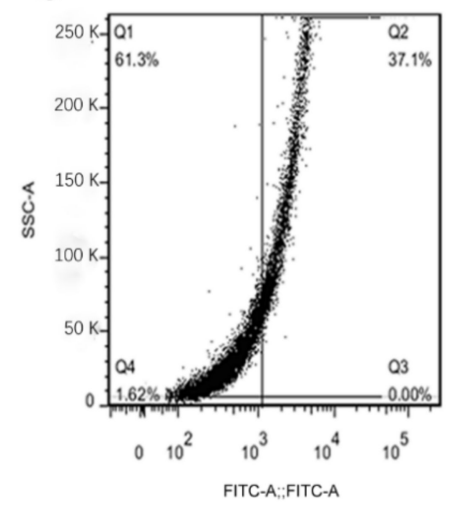

Figure 9. Flow cytometry analysis. Cells in the exponential phase of X. oryzae pv. oryzae (A-C) were treated with the peptides and analyzed for cell fluorescence by flow cytometry. The delta fluorescence signal indicates the propidium iodide (PI) uptake caused by peptide treatment. (A): no peptide (negative control, 0.07\%); (B) OrR935 (MIC, 23.9\%); (C) OrR214 (MIC, 37.1\%). The $x$-axis indicates the average intensity of the fluorescence, and the $y$-axis displays the light from the side scatter. Experiments under the same conditions were replicated three times, and similar findings were noted.

\subsection{Antimicrobial Mechanisms of Peptides OrR214 and OrR935}

To establish the bacteriostatic effect of antimicrobial peptides, the morphological changes in the cells were obtained by scanning electron microscopy (SEM) and transmission electron microscopy (TEM) (Figure 10). The results showed that the control had complete and smooth surfaces and no membrane damage. In comparison, the bacteria treated with antimicrobial peptide OrR214 (Figure 10BI-III) had severe damage to the cell membrane surface, and their integrity was destroyed, while the bacterial cells treated with antimicrobial peptide OrR935 (Figure 10CI-III) even had cell contents released to the cells. These findings provide a potential theoretical basis for the mechanism of cell membrane damage caused by antimicrobial peptides.

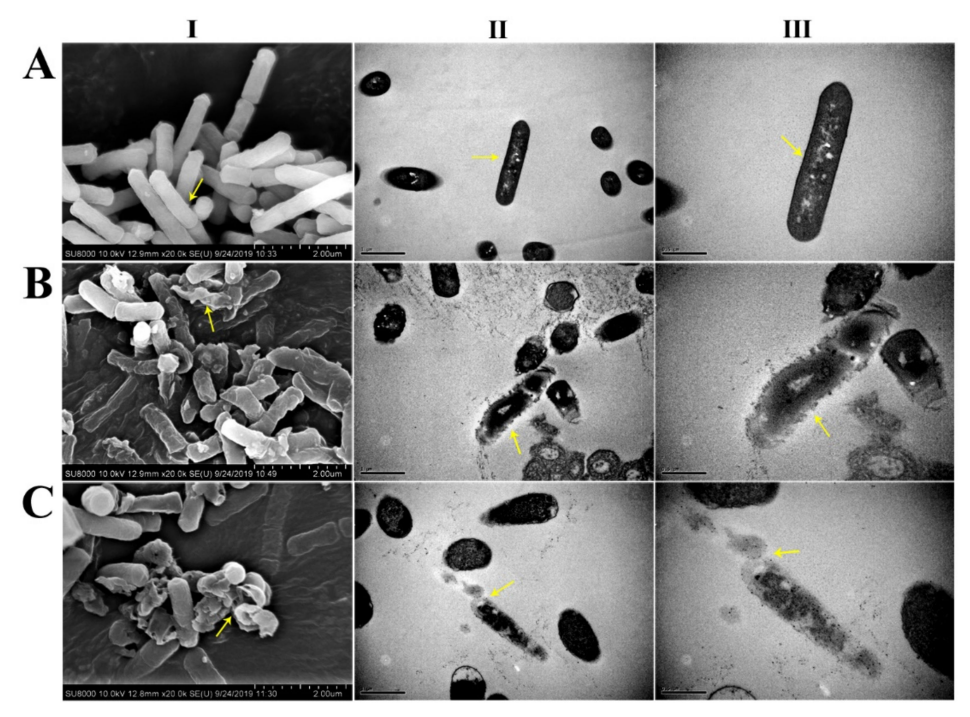

Figure 10. Cell membrane damage of $X$. oryzae pv. oryzae cells treated with two antimicrobial peptides (OrR214 and OrR935) at their MICs. Before the samples were coated with gold, glutaraldehyde was used for freeze-drying. (A-I) PBS, (B-I) OrR214, and (C-I) OrR935 were examined under the scanning electron microscope. (A-II) PBS, (B-II) OrR214, and (C-II) OrR935 were examined at $1 \mu \mathrm{m}$ resolution under the transmission electron microscope. (A-III) PBS, (B-III) OrR214, and (C-III) OrR935 were examined at $0.5 \mu \mathrm{m}$ resolution under the transmission electron microscope. Treatment with PBS was used as a control. The yellow arrows indicate major differences in different treatments. 


\section{Discussion}

The increasing resistance of microorganisms to traditional antibiotics is a global public health concern that needs significant attention for mitigation. Because of their broad-spectrum antibacterial and antifungal properties, the potential for AMPs as substitutes for antibiotics has increased [44]. AMPs can also function in different ways on microbial cell membranes, reducing the development of drug resistance to a certain extent [45]. B. subtilis has a unique ability, even at high concentrations, to secrete peptides in its surroundings, thus reducing the toxicity of host cells through its soluble secretory properties [46]. By using the B. subtilis expression system, we developed a new, sensitive and high-throughput technique to isolate novel AMPs [27]. Throughout this study, we identified 6 different candidate genes from a storage capacity of 3114 clones of the O. rufipogon cDNA library. Two distinct peptides, OrR214 and OrR935, showing significant antimicrobial properties were selected for further study. Due to the accumulation of expressed extracellular peptides, these peptides had certain toxic effects on the host cells, resulting in abnormal changes in the phenotypes of the recombinant strains (Figure 1).

At present, there are more than 4800 AMPs in the DRAMP (Data repository of antimicrobial peptides) database (http://dramp.cpu-bioinfor.org/), where the majority of peptides are effective against Gram-positive bacteria [47]. Our system provides a new strategy for screening AMPs from the above findings because it exhibited better antimicrobial activity not only against Gram-positive bacteria but also against Gram-negative bacteria. According to this study, the candidate peptides isolated encode 20-40 amino acids (Table S4). In addition, the results showed that the structures, isoelectric points (IPs) and hydrophilicities of antimicrobial peptides affect their antibacterial activity [48-50]. In our study, the biological information of the obtained antimicrobial peptides was also predicted. These peptides mostly contain an $\alpha$-helix structure and amphiphilicity, high IPs and have some potential antimicrobial properties against Gram-positive and Gram-negative bacteria. As predicted, the peptides OrR214 and OrR935 displayed the correct molecular sizes, which can be seen from Supplementary Figure S4.

The physical interaction between the AMPs and the bacterial cell membrane has been reported to occur during the resistance process $[44,51,52]$. It is worth noting that during the experiment, the antimicrobial activity was partially lost due to the addition of physiological salts [53]. Some studies indicate that because AMPs contain a hydrophobic residue cation, they can interact with a negative charge on the outer membrane of the bacterial cell and thus contribute to the role of the peptide in the membrane of the bacterial cell $[54,55]$. In this study, when treated with a solution containing calcium, sodium and magnesium ions at low concentrations, the activity of the peptides OrR214 and OrR935 was not significantly inhibited; however, the activities of these two peptides were slightly decreased at maximum sodium ion concentrations (Figure 8A,B).

Antimicrobial genes have different effects on bacteria than traditional antibiotics. For instance, the resistance mechanism of AMPs to bacteria has also been studied. The findings are still preliminary, but it has been stated that through electrostatic interaction with the cell membrane, the cationic region of the AMPs attacks the cells, thus destroying the bacteria. Most AMPs are known to act on the bacterial plasma membrane, and there is no particular target site [56]. The confocal microscopy images and electron microscopy (both SEM and TEM) findings in our study showed damage to the cytomembrane (distortion, pore formation, shrinkage, and ruptures), leading to bacterial death, which induces PI to enter the cells and bind DNA. Meanwhile, PI can penetrate the cell membranes and release red fluorescence, which is responsible for most of the breakdown of the cell. Based on these findings, we predicted that the potential working mechanism of the OrR214 and OrR935 peptides was rupture of the cell membrane.

In addition, our findings (Figure S6) have shown that antimicrobial peptides can also induce the formation of reactive oxygen species. Most molecules in cells, including nucleic acids and proteins, may be killed by ROS, resulting in antibacterial actions, although it is difficult to establish the particular target points of action. While this finding is consistent with previous findings, further analysis is still needed to determine the unique mechanisms employed by these two peptides [57]. Even though 
antimicrobial peptides have broad-spectrum antimicrobial activity, their development and application still have some safety issues. Some antimicrobial peptides have been demonstrated to be toxic to mammalian cells in previous studies [58,59].

\section{Materials and Methods}

\subsection{Maintenance of Plant and Pathogen Cultures}

The China Germplasm Resources Conservation Center supplied the Zhangpu wild rice, and the seeds were immersed in a petri dish for $3 \mathrm{~d}$ before germination. The cultures of Rhizoctonia solani were taken from our laboratory. Before use, the cells were inoculated on a PDA plate and cultured in a $28^{\circ} \mathrm{C}$ incubator. After 3-4 generations of activation, $R$. solani was inoculated at the tillering stage of rice, and leaves were collected every $6 \mathrm{~h}$ until the onset of rice [60]. All indicator bacteria used in this experiment were isolated and collected by our lab.

\subsection{Construction of the cDNA Library and Quality Assessment}

The fundamental steps of the construction of the cDNA library are as follows: total RNA extraction from leaves using the TRIzol method, mRNA purification using the PolyATtractR mRNA isolation system (Promega, Madison, WI, USA), inverting and synthesizing using a cDNA kit (Takara Biomedical Technology, Dalian, China), adding the same cleavage site to the vector at the end of cDNA by PCR and ligating with the PBE-S vector, and finally transforming to the HST08 expression system. Transformants were picked randomly from each plate for PCR detection to evaluate the quality of the cDNA library. The pBE-S-F (5'-GTTATTTCGAGTCTCTACGG-3') and pBE-S-R (5'-TAACCAAGCCTATGCCTACA-3') primers were used to confirm the consistency of the cDNA library colonies and were then stored at $-80{ }^{\circ} \mathrm{C}$ [61]. Primers for O. rufipogon library construction and purified peptides are presented in Supplementary Table S2.

\subsection{Candidate Resistance Gene Screening and Confirmation from cDNA Libraries}

As with the previously mentioned method $[27,43]$, initial screening and confirmation were carried out. The plasmid population was extracted and transferred into B. subtilis SCK6. All single colonies were picked and placed in $2 \mathrm{~mL}$ Eppendorf tubes containing kanamycin $(10 \mathrm{mg} / \mathrm{L}) \mathrm{LB}$ medium and stored at $37^{\circ} \mathrm{C}(4-6 \mathrm{~h}, 180 \mathrm{rpm})$. After that, on the LB plate containing kanamycin, $1 \mu \mathrm{L}$ of each single colony was placed, and the morphology of the colony was observed every $12 \mathrm{~h}$. The strains with abnormal phenotypes (autolysis) were recorded and verified repeatedly.

\subsection{Expression of the Antimicrobial Peptide Against Pathogenic Bacteria and Thermal Stability}

The extracellular peptides secreted by the $B$. subtilis expression system were extracted by the ammonium sulfate precipitation method to determine the biological activity of antimicrobial peptides. For the measurement of bacterial bioresistance, an agar diffusion test (filter paper method) was used, in which the peptide was dropped on filter paper on an indicator plate [43]. Stability experiments were conducted to verify the strength of the antimicrobial peptides against different temperatures and enzymes. The antimicrobial peptides were heated for $30 \mathrm{~min}$ at $4{ }^{\circ} \mathrm{C}, 50^{\circ} \mathrm{C}, 70{ }^{\circ} \mathrm{C}$, and $100{ }^{\circ} \mathrm{C}$ for thermal stability testing. Then, AMPs were treated with $100 \mu \mathrm{g} / \mathrm{mL}$ lipase $\left(30^{\circ} \mathrm{C}\right)$, pepsin and trypsin $\left(37^{\circ} \mathrm{C}\right)$ and papain, amylase, peptidase $\mathrm{K}$, and protease $\mathrm{E}\left(55^{\circ} \mathrm{C}\right)$ for $1 \mathrm{~h}$ to measure the effects of the enzymes on the AMPs. The agar diffusion test was performed on two Gram-negative ( $R$. solanacearum and X. oryzae pv. oryzae) and Gram-positive (C. michiganensis subsp and C. fangii) bacteria. Importantly, we confirmed that the pure antimicrobial peptides (after purification) were also stable under higher temperatures and were insensitive to enzymes. 


\subsection{His-Tag Fusion Peptide Purification}

The genes OrR214 and OrR935 were engineered by a $6 \times$ His tag purification process, and a segment of the protease (TEV) sequence was inserted between the vector (PBE-S) signal peptide and the target fragment and then transformed into a B. subtilis expression system. The detailed methods and recombination peptide sequences for obtaining pure AMPs are presented in Supplementary Method 1 and Table S1. TEV protease is a highly specific cysteine protease that recognizes the amino-acid sequence Glu-Asn-Leu-Tyr-Phe-Gln-(Gly/Ser) and cleaves between the Gln and Gly/Ser residues. This protease is commonly used to remove His-Tags of fusion proteins. There was only one additional Gly/Ser amino acid residue at the $\mathrm{N}$ end of the target protein after His-label was digested, thus decreasing the effects on the structure and function of the target protein and obtaining pure peptides. The remaining purified peptide was digested with TEV protease at $4{ }^{\circ} \mathrm{C}$ overnight. To remove TEV (His-Tag), the solution was passed through a Ni-NTA His Bind Resin. The peptide was concentrated in an ultrafiltration tube, and then the solvent was exchanged with PBS. Finally, the peptides were concentrated and recovered for subsequent experiments. First, $40 \mu \mathrm{L}$ of purified peptide was boiled for $10 \mathrm{~min}$ in a water bath with $10 \mu \mathrm{L}$ of $5 \times$ peptide loading buffer. Next, a Tricine-SDS-PAGE kit was used to resolve $25 \mu \mathrm{L}$ of the mixed sample onto a polyacrylamide gel using a Tricine-SDS-PAGE kit. A list of specific primers for obtaining pure AMPs and detailed purification method was presented in Supplementary Table S1 and Method S1.

\subsection{Minimum Inhibitory Concentration (MIC) and Growth Time-Kill Curve Analyses}

A microtiter broth dilution method $[62,63]$ was used to determine the MICs of antimicrobial peptides. For these tests, the bacterial inoculum was prepared in LB liquid medium (OD600 $\approx 0.02-0.05$ ) and added to a 96-well titration plate. Serial dilutions of equal amounts of peptides were then performed, and the plates were incubated at $28^{\circ} \mathrm{C}$ for $24 \mathrm{~h}$. The lowest peptide concentration of bacteria was recorded without visible growth at the MIC value using ELISA (SPARK). The concentration of purified antimicrobial peptides was modified to the MIC level for determination of time-kill analysis, and the same volume as the indicator bacteria was applied to the 96-well plate (at least three wells per concentration). Then, the plate was mixed and incubated for $2,4,6,8,10,12$, and $24 \mathrm{~h}$ at $28^{\circ} \mathrm{C}$. After that, the OD was measured at $600 \mathrm{~nm}$. Inhibition assays for $M$. oryzae were performed as described previously with slight modifications [64]. Nearly $200 \mu \mathrm{L}$ of peptide was mixed with $5 \mathrm{~mL}$ of semisolid PDA media for a final concentration of $260 \mu \mathrm{g} / \mathrm{mL}$ and was spread on previously prepared PDA plates. The plates were then seeded with $5 \times 5 \mathrm{~mm}$ mycelial plugs collected from the edges of $4 \mathrm{~d}$ M. oryzae colonies (P131), followed by incubation at $28^{\circ} \mathrm{C}$. The buffer was used as a control, and the data were recorded at $96 \mathrm{~h}$. First, approximately $200 \mu \mathrm{L}$ of peptides was added into PDA media with hyphae of F. graminearum and then cultured at $28^{\circ} \mathrm{C}$ for $72 \mathrm{~h}$. Second, the antimicrobial peptides were mixed evenly with the spores of $F$. graminearum $\left(10^{7} / \mathrm{mL}\right)$ and cultured at $28^{\circ} \mathrm{C}$. The number of spore eruptions was observed and recorded every $2 \mathrm{~h}$.

\subsection{Salt Dependence Test}

The steps of these tests are similar to the previous MIC determination except for the treatment method of the antimicrobial peptides. To detect the activity of the antimicrobial peptide, the solution $(1 \times \mathrm{MIC})$ was treated with different concentrations of $\mathrm{NaCl}(50,100$, and $150 \mathrm{mM}), \mathrm{CaCl}_{2}(1.25,2.5$, and $5 \mathrm{mM}), \mathrm{MgCl}_{2}(0.5,1$, and $2 \mathrm{mM})$, or $\mathrm{KCl}(1.5,3$, and $4.5 \mathrm{mM})$, and the OD values were detected at a wavelength of $600 \mathrm{~nm}$ using ELISA (SPARK) $[65,66]$.

\subsection{Hemolytic Assay}

The hemolytic activity of the two antimicrobial peptides was evaluated according to a previously described method [58]. Briefly, freshly prepared porcine erythrocyte cells were centrifuged $(1500 \times g)$ for $10 \mathrm{~min}$ at $4{ }^{\circ} \mathrm{C}$ and the cells were harvested, washed three times with precooled PBS solution and 
diluted with PBS. An equal volume of diluted red blood cells and antimicrobial peptide solutions $(1 \times \mathrm{MIC}, 1.5 \times \mathrm{MIC}, 2 \times \mathrm{MIC}, 2.5 \times \mathrm{MIC}$, and $3 \times \mathrm{MIC})$ were incubated for $1 \mathrm{~h}$ at $37^{\circ} \mathrm{C}$ and centrifuged at $4000 \times \mathrm{g}$ for $10 \mathrm{~min}$. Using an ELISA (SPARK) plate reader, the supernatant was taken in a 96-well plate, and the absorbance was measured at $385 \mathrm{~nm}$. A $0.1 \%$ Triton X-100 erythrocyte suspension was used as a control group, while a mixture incubated only with PBS buffer was used as a negative control. In addition, the percentage of hemolysis was determined with $0.1 \%$ Triton X-100 in PBS. The percentage of hemolytic activity was calculated as follows: $\left[\left(\mathrm{A}_{\text {peptide }}-\mathrm{A}_{\mathrm{PBS}}\right) /\left(\mathrm{A}_{\text {Triton }}-\mathrm{A}_{\mathrm{PBS}}\right)\right] \times 100$.

\subsection{Reactive Oxygen Species (ROS) Determination Test}

The fluorescence assay of DCFH-DA was used to measure the production of ROS [67]. In this experiment, $X$. oryzae pv. oryzae was cultured in liquid LB medium in the logarithmic phase, and the same volumes of OrR214 and OrR935 (MIC) antimicrobial peptides were applied. Then, $10 \mu \mathrm{M}$ of DCFH-DA was added to the medium and incubated at $28^{\circ} \mathrm{C}$ for different periods $(15,30,60,90$, and $120 \mathrm{~min}$ ). Samples were centrifuged at $5000 \times \mathrm{g}$ for $10 \mathrm{~min}$ following incubation. The pellet was rinsed 2-3 times with PBS, and the cell pellet was resuspended in PBS. An ELISA (SPARK) microplate reader (excitation $485 \mathrm{~nm}$ and emission $540 \mathrm{~nm}$ ) measured the fluorescence intensity of the resuspended cells and observed them with a fluorescence microscope to capture images.

\subsection{Detection of Cell Membrane Permeability}

The membrane permeability of the cells treated with the antimicrobial peptides was examined by confocal microscopy and flow cytometry $[27,68]$. The bacterial cells were cultured to the logarithmic growth phase, and the concentration was adjusted to $\mathrm{OD}_{600}(0.1-0.2)$ and incubated with antimicrobial peptides OrR214 and OrR935 at the MICs for $2 \mathrm{~h}$ at $28^{\circ} \mathrm{C}$. After centrifugation, the pellet was washed 2-3 times with PBS, resuspended, treated with $5 \mu \mathrm{L}$ of PI, and the sample was then incubated at $4{ }^{\circ} \mathrm{C}$ for approximately $15 \mathrm{~min}$ in the dark. Then, the pellet was centrifuged, washed 2-3 times with PBS, and resuspended in $200 \mu \mathrm{L}$ of PBS for FOW cell detection. Fluorescence intensity images were acquired using a FACSVerse machine (BD, USA) and analyzed using FlowJo. 7.6.1, Min software (BD, USA).

\subsection{Electron Microscopy Analysis}

The cells were pelleted by shaking the X. oryzae pv. oryzae at $28^{\circ} \mathrm{C}$ to the logarithmic growth phase. The antimicrobial peptides with MICs were co-incubated for $2 \mathrm{~h}$ at $28^{\circ} \mathrm{C}$, and the autolyzed strains (OrR214 and OrR935) were shaken at $37^{\circ} \mathrm{C}$ for $60 \mathrm{~h}$ and then centrifuged at $1000 \times g$ for $5 \mathrm{~min}$. After washing 2-3 times with sterilized PBS ( $\mathrm{pH} 7.4$ ), the cells were resuspended and obtained an OD of 0.8 (at $600 \mathrm{~nm}$ ). The cells were then extracted at $5000 \times g$ for $5 \mathrm{~min}$ by centrifugation, resuspended in $2.5 \%$ glutaraldehyde to stabilize the cell pellet for $2-4 \mathrm{~h}$ and rinsed thoroughly with PBS twice and with different gradients of ethanol (30\%, 50\%, 70\%, and 90\%). Finally, the samples were washed with $100 \%$ ethanol for approximately $10 \mathrm{~min}$, dried overnight in a freeze dryer and inspected on a HITACHI S-4800 SEM [69]. For transmission electron microscopy analysis, the obtained cells were centrifuged (each treatment with $3 \%$ glutaraldehyde for $2 \mathrm{~h}$ ) and then washed 3 times with $0.1 \mathrm{M}$ phosphate buffer (pH 7). The cells were further fixed with $1 \%$ osmium tetroxide, and then samples were washed 3 times with sterile distilled water and stained with $2 \%$ uranyl acetate solution. The stained samples were eluted with different concentrations of ethanol $(70 \%, 80 \%, 90 \%$, and $100 \%)$, with each step requiring $15 \mathrm{~min}$. The dehydrated sample was soaked with $100 \%$ propylene oxide for $15 \mathrm{~min}$, washed two times, and the epoxy resin and propylene oxide were embedded at 1:1 for $1 \mathrm{~h}$. The embedded sample was placed in a mold, freeze-dried at $-80^{\circ} \mathrm{C}$ for $12 \mathrm{~h}$, sliced by an ultrathin microtome, and observed under a HITACHI H-7650 transmission electron microscope. 


\subsection{Pathogenicity Assay}

To assess the pathogenicity of X. oryzae pv. oryzae, the method described in the previous article was used with minor modifications [70]. Leaves $10 \mathrm{~cm}$ long were cut with sterile scissors. The cells were pelleted by shaking the $\mathrm{X}$. oryzae pv. oryzae at $28^{\circ} \mathrm{C}$ to logarithmic growth phase, and the same volume of antimicrobial peptides was added. Then, the mixture was dipped with sterile scissors, and the tip of the leaf was cut off and cultured at $28^{\circ} \mathrm{C}$ for $7 \mathrm{~d}$. Each treatment was performed on 4 leaves and repeated 3 times.

\section{Conclusions}

Two novel antimicrobial peptides with broad-spectrum antibacterial activities from O. rufipogon were screened in this study. These two peptides have high thermal, enzymatic, and cationic stabilities and are nontoxic to mammalian cells. In addition, we also found that these two antimicrobial peptides can act on the cell membrane, causing damage. Based on these distinguishing features, we speculated that these two antimicrobial peptides could be used as promising raw materials for drug development.

Supplementary Materials: The supplementary material for this article can be found online http://www.mdpi.com/ 1422-0067/21/22/8722/s1, Figure S1. Insertion of the cDNA library of B. subtilis system, Figure S2. The germination rate of F. graminearum spore, Figure S3. The antimicrobial peptide inhibitory activity on the M. oryzae spore, Figure S4. Detection of fusion peptides via SDS-PAGE, Figure S5. Analysis of Time-Kill curve, Figure S6. Antimicrobial peptides OrR214 and OrR935 caused the reactive oxygen species production in X. oryzae pv. oryzae cells, Table S1. Sequences for His-Tag Fusion Peptide, Table S2. Primers and sequences for building the O. rufipogon library and purifying the proteins, Table S3. The bacteriostatic spectrum of the antimicrobial genes of O. rufipogon, Table S4. Bioinformatics prediction of antibacterial peptide, Method S1: His-tag fusion peptide purification.

Author Contributions: J.L. and W.D. conceived and designed the experiments. J.L. and P.G. performed the experiments. J.L., S.I., and W.D. analyzed the data. J.L., S.I. and X.H. contributed to formal analysis. J.L., S.I., and W.D. wrote the manuscript with input from all co-authors. All authors have read and agreed to the published version of the manuscript.

Funding: This work was supported by The National Major Project for Transgenic Organism Breeding (2016ZX08003-001).

Acknowledgments: The material was supported by Wild Rice Section, Resource Center, Crop Science Institute, Chinese Academy of Agricultural Sciences.

Conflicts of Interest: The authors declare no conflict of interest.

\section{References}

1. Li, B.; Webster, T.J. Bacteria antibiotic resistance: New challenges and opportunities for implant-associated orthopedic infections. J. Orthop. Res. 2017, 36, 22-32. [CrossRef] [PubMed]

2. Zheng, J.; Li, J.; Zhang, L.; Chen, X.; Yu, Y.-D.; Huang, H. Post-graphene 2D materials-based antimicrobial agents: Focus on fabrication strategies and biosafety assessments. J. Mater. Sci. 2020, 55, 7226-7246. [CrossRef]

3. Bin Zaman, S.; Hussain, M.A.; Nye, R.; Mehta, V.; Mamun, K.T.; Hossain, N. A Review on Antibiotic Resistance: Alarm Bells are Ringing. Cureus 2017, 9, e1403. [CrossRef] [PubMed]

4. Reygaert, W.C. An overview of the antimicrobial resistance mechanisms of bacteria. AIMS Microbiol. 2018, 4, 482-501. [CrossRef]

5. $\mathrm{Xu}, \mathrm{H}$.; Wang, F. Research Advances of Antimicrobial Peptides and Applications in Food Industry and Agriculture. Curr. Protein Pept. Sci. 2010, 11, 264-273. [CrossRef]

6. Islam, S.; Mahmud, S.; Sultana, R.; Dong, W. Identification and in silico molecular modelling study of newly isolated Bacillus subtilis SI-18 strain against S9 protein of Rhizoctonia solani. Arab. J. Chem. 2020. [CrossRef]

7. Lin, P.; Wong, J.H.; Ng, T.B. A defensin with highly potent antipathogenic activities from the seeds of purple pole bean. Biosci. Rep. 2009, 30, 101-109. [CrossRef]

8. Fu, T.; Islam, S.; Ali, M.; Wu, J.; Dong, W. Two antimicrobial genes from Aegilops tauschii Cosson identified by the Bacillus subtilis expression system. Sci. Rep. 2020, 10, 1-11. [CrossRef] 
9. Jung, Y.-J.; Lee, S.-Y.; Moon, Y.-S.; Kang, K.-K. Enhanced resistance to bacterial and fungal pathogens by overexpression of a human cathelicidin antimicrobial peptide (hCAP18/LL-37) in Chinese cabbage. Plant Biotechnol. Rep. 2012, 6, 39-46. [CrossRef]

10. Qutb, A.M.; Wei, F.; Dong, W. Prediction and Characterization of Cationic Arginine-Rich Plant Antimicrobial Peptide SM-985 From Teosinte (Zea mays ssp. mexicana). Front. Microbiol. 2020, 11, 1353. [CrossRef]

11. Zhu, X.; Zhang, L.; Wang, J.; Ma, Z.; Xu, W.; Li, J.; Shan, A. Characterization of antimicrobial activity and mechanisms of low amphipathic peptides with different $\alpha$-helical propensity. Acta Biomater. 2015, 18, 155-167. [CrossRef] [PubMed]

12. Ganewatta, M.S.; Tang, C. Controlling macromolecular structures towards effective antimicrobial polymers. Polymer 2015, 63, A1-A29. [CrossRef]

13. Liu, S.; Wang, J.; Feng, Y.; Ye, Q.; Wen, L.; Xu, G.; Zou, J. Effects of compound antimicrobial peptides on the growth performance, antioxidant and immune responses and disease resistance of grass carp (Ctenopharyngodon idellus). Fish Shellfish. Immunol. 2020, 107, 163-170. [CrossRef] [PubMed]

14. Souza, P.F.N.; Marques, L.S.; Oliveira, J.T.; Lima, P.G.; Dias, L.P.; Neto, N.A.; Lopes, F.E.; Sousa, J.S.; Silva, A.F.; Caneiro, R.F.; et al. Synthetic antimicrobial peptides: From choice of the best sequences to action mechanisms. Biochimie 2020, 175, 132-145. [CrossRef]

15. Hancock, R.E.; Haney, E.F.; Gill, E.E. The immunology of host defense peptides: Beyond antimicrobial activity. Nat. Rev. Immunol. 2016, 16, 321-334. [CrossRef]

16. Mishra, B.; Wang, X.; Lushnikova, T.; Zhang, Y.; Golla, R.M.; Narayana, J.L.; Wang, C.; McGuire, T.R.; Wang, G. Antibacterial, antifungal, anticancer activities and structural bioinformatics analysis of six naturally occurring temporins. Peptides 2018, 106, 9-20. [CrossRef]

17. Li, C.; Zhu, J.; Wang, Y.; Chen, Y.; Song, L.; Zheng, W.; Li, J.; Yu, R. Antibacterial Activity of AI-Hemocidin 2, a Novel N-Terminal Peptide of Hemoglobin Purified from Arca inflata. Mar. Drugs 2017, 15, 205. [CrossRef]

18. Lin, M.-C.; Lin, S.-B.; Lee, S.-C.; Lin, C.-C.; Hui, C.-F.; Chen, J.-Y. Antimicrobial peptide of an anti-lipopolysaccharide factor modulates of the inflammatory response in RAW264.7 cells. Peptides 2010, 31, 1262-1272. [CrossRef]

19. Shenkarev, Z.; Balandin, S.V.; Trunov, K.I.; Paramonov, A.S.; Sukhanov, S.V.; Barsukov, L.I.; Arseniev, A.S.; Ovchinnikova, T.V. Molecular Mechanism of Action of $\beta$-Hairpin Antimicrobial Peptide Arenicin: Oligomeric Structure in Dodecylphosphocholine Micelles and Pore Formation in Planar Lipid Bilayers. Biochemistry 2011, 50, 6255-6265. [CrossRef]

20. Jindal, H.M.; Zandi, K.; Ong, K.C.; Velayuthan, R.D.; Rasid, S.M.; Samudi Raju, C.; Sekaran, S.D. Mechanisms of action and in vivo antibacterial efficacy assessment of five novel hybrid peptides derived from Indolicidin and Ranalexin against Streptococcus pneumoniae. Peer] 2017, 5, e3887. [CrossRef]

21. Wang, K.; Yan, J.; Liu, X.; Zhang, J.; Chen, R.; Zhang, B.; Dang, W.; Zhang, W.; Kai, M.; Song, J.; et al. Novel cytotoxity exhibition mode of polybia-CP, a novel antimicrobial peptide from the venom of the social wasp Polybia paulista. Toxicology 2011, 288, 27-33. [CrossRef] [PubMed]

22. Maróti, G.; Kereszt, A.; Kondorosi, E.; Mergaert, P. Natural roles of antimicrobial peptides in microbes, plants and animals. Res. Microbiol. 2011, 162, 363-374. [CrossRef]

23. Oh, R.; Lee, M.J.; Kim, Y.-O.; Nam, B.-H.; Kong, H.J.; Kim, J.-W.; Park, J.-Y.; Seo, J.-K.; Kim, D.-G. Purification and characterization of an antimicrobial peptide mytichitin-chitin binding domain from the hard-shelled mussel, Mytilus coruscus. Fish Shellfish Immunol. 2018, 83, 425-435. [CrossRef] [PubMed]

24. Oh, R.; Lee, M.J.; Kim, Y.-O.; Nam, B.-H.; Kong, H.J.; Kim, J.-W.; Park, J.-Y.; Seo, J.-K.; Kim, D.-G. Myticusin-beta, antimicrobial peptide from the marine bivalve, Mytilus coruscus. Fish Shellfish Immunol. 2020, 99, 342-352. [CrossRef] [PubMed]

25. Ladram, A. Antimicrobial peptides from frog skin biodiversity and therapeutic promises. Front. Biosci. 2016, 21, 1341-1371. [CrossRef] [PubMed]

26. Mygind, P.H.; Fischer, R.L.; Schnorr, K.M.; Hansen, M.T.; Sönksen, C.P.; Ludvigsen, S.; Raventós, D.; Buskov, S.; Christensen, B.; De Maria, L.; et al. Plectasin is a peptide antibiotic with therapeutic potential from a saprophytic fungus. Nat. Cell Biol. 2005, 437, 975-980. [CrossRef]

27. Kong, X.; Yang, M.; Abbas, H.M.K.; Wu, J.; Li, M.; Dong, W. Antimicrobial genes from Allium sativum and Pinellia ternata revealed by a Bacillus subtilis expression system. Sci. Rep. 2018, 8, 14514. [CrossRef]

28. Fjell, C.D.; Jenssen, H.; Cheung, W.A.; Hancock, R.E.W.; Cherkasov, A. Optimization of Antibacterial Peptides by Genetic Algorithms and Cheminformatics. Chem. Biol. Drug Des. 2010, 77, 48-56. [CrossRef] 
29. Rosano, G.L.; Ceccarelli, E.A. Recombinant protein expression in Escherichia coli: Advances and challenges. Front. Microbiol. 2014, 5, 172. [CrossRef]

30. Ling, J.; Liu, Z.; Tong, T.; Fan, H.; Zhang, D.; Chen, H.; Guo, A. Construction and Eukaryotic Expression of Recombinant Plasmid Encoding Fusion Protein of Goat Complement C3d and Foot-and-Mouth Disease Virus VP1. Chin. J. Biotechnol. 2008, 24, 209-213. [CrossRef]

31. Groisillier, A.; Hervé, C.; Jeudy, A.; Rebuffet, E.; Pluchon, P.F.; Chevolot, Y.; Flament, D.; Geslin, C.; Morgado, I.; Power, D.M.; et al. MARINE-EXPRESS: Taking advantage of high throughput cloning and expression strategies for the post-genomic analysis of marine organisms. Microb. Cell Factories 2010, 9, 45. [CrossRef] [PubMed]

32. Khow, O.; Suntrarachun, S. Strategies for production of active eukaryotic proteins in bacterial expression system. Asian Pac. J. Trop. Biomed. 2012, 2, 159-162. [CrossRef]

33. Wenzel, M.; Müller, A.; Siemann-Herzberg, M.; Altenbuchner, J. Self-Inducible Bacillus subtilis Expression System for Reliable and Inexpensive Protein Production by High-Cell-Density Fermentation. Appl. Environ. Microbiol. 2011, 77, 6419-6425. [CrossRef] [PubMed]

34. Zhao, Q.; Feng, Q.; Lu, H.; Li, Y.; Wang, A.; Tian, Q.; Zhan, Q.; Lu, Y.; Zhang, L.; Huang, T.; et al. Pan-genome analysis highlights the extent of genomic variation in cultivated and wild rice. Nat. Genet. 2018, 50, 278-284. [CrossRef] [PubMed]

35. Song, Z.; Li, B.; Chen, J.; Lu, B.-R. Genetic diversity and conservation of common wild rice (Oryza rufipogon) in China. Plant Species Biol. 2005, 20, 83-92. [CrossRef]

36. Tian, F.; Li, D.J.; Fu, Q.; Zhu, Z.F.; Fu, Y.C.; Wang, X.K.; Sun, C. Construction of introgression lines carrying wild rice (Oryza rufipogon Griff.) segments in cultivated rice (Oryza sativa L.) background and characterization of introgressed segments associated with yield-related traits. Theor. Appl. Genet. 2006, 112, 570-580. [CrossRef] [PubMed]

37. Zhou, Y.; Yang, P.; Cui, F.; Zhang, F.; Luo, X.; Xie, J. Transcriptome Analysis of Salt Stress Responsiveness in the Seedlings of Dongxiang Wild Rice (Oryza rufipogon Griff.). PLoS ONE 2016, 11, e0146242. [CrossRef]

38. Liu, W.; Ghouri, F.; Yu, H.; Li, X.; Yu, S.; Shahid, M.Q.; Liu, X. Genome wide re-sequencing of newly developed Rice Lines from common wild rice (Oryza rufipogon Griff.) for the identification of NBS-LRR genes. PLoS ONE 2017, 12, e0180662. [CrossRef]

39. Zhai, C.; Dong, Z.; He, X.; Zeng, X.; Wang, L.; Lin, F.; Yuan, B.; Pan, Q. The isolation and characterization of Pik, a rice blast resistance gene which emerged after rice domestication. New Phytol. 2010, 189, 321-334. [CrossRef]

40. Das, A.; Soubam, D.; Singh, P.K.; Thakur, S.; Sharma, T.R. A novel blast resistance gene, Pi54rh cloned from wild species of rice, Oryza rhizomatis confers broad spectrum resistance to Magnaporthe oryzae. Funct. Integr. Genom. 2012, 12, 215-228. [CrossRef]

41. Hong-Jing; Xiang-Hua; Jing-Hua; Xiao; Shi-Ping; Wang. Ortholog Alleles at Xa3/Xa26 Locus Confer Conserved Race-Specific Resistance against Xanthomonas oryzae in Rice. Mol. Plant 2012, 5, 281-290. [CrossRef] [PubMed]

42. Lv, Q.; Xu, X.; Shang, J.; Jiang, G.; Pang, Z.; Zhou, Z.; Wang, J.; Liu, Y.; Li, T.; Li, X.; et al. Functional Analysis of Pid3-A4, an Ortholog of Rice Blast Resistance Gene Pid3 Revealed by Allele Mining in Common Wild Rice. Phytopathology 2013, 103, 594-599. [CrossRef] [PubMed]

43. Wu, J.; Abbas, H.M.K.; Li, J.; Yuan, Y.; Liu, Y.; Wang, G.; Dong, W. Cell Membrane-Interrupting Antimicrobial Peptides from Isatis indigotica Fortune Isolated by a Bacillus subtilis Expression System. Biomolecules 2019, 10, 30. [CrossRef] [PubMed]

44. Maria-Neto, S.; De Almeida, K.C.; Macedo, M.L.R.; Franco, O.L. Understanding bacterial resistance to antimicrobial peptides: From the surface to deep inside. Biochim. Biophys. Acta Biomembr. 2015, 1848, 3078-3088. [CrossRef] [PubMed]

45. Yeung, A.T.Y.; Gellatly, S.L.; Hancock, R.E. Multifunctional cationic host defence peptides and their clinical applications. Cell. Mol. Life Sci. 2011, 68, 2161-2176. [CrossRef] [PubMed]

46. Ho, K.M.; Lim, B.L. Co-expression of a prophage system and a plasmid system in Bacillus subtilis. Protein Expr. Purif. 2003, 32, 293-301. [CrossRef]

47. Fan, L.; Sun, J.; Zhou, M.; Zhou, J.; Lao, X.; Zheng, S.; Xu, H. DRAMP: A comprehensive data repository of antimicrobial peptides. Sci. Rep. 2016, 6, 24482. [CrossRef] [PubMed] 
48. Hazam, P.K.; Goyal, R.; Ramakrishnan, V. Peptide based antimicrobials: Design strategies and therapeutic potential. Prog. Biophys. Mol. Biol. 2019, 142, 10-22. [CrossRef]

49. Wimley, W.C. Describing the Mechanism of Antimicrobial Peptide Action with the Interfacial Activity Model. ACS Chem. Biol. 2010, 5, 905-917. [CrossRef]

50. Wang, G.; Li, X.; Wang, Z. APD3: The antimicrobial peptide database as a tool for research and education. Nucleic Acids Res. 2016, 44, D1087-D1093. [CrossRef]

51. Zucca, M.; Scutera, S.; Savoia, D. New Antimicrobial Frontiers. Mini Rev. Med. Chem. 2011, 11, 888-900. [CrossRef] [PubMed]

52. Huang, Y.; Huang, J.; Chen, Y. Alpha-helical cationic antimicrobial peptides: Relationships of structure and function. Protein Cell 2010, 1, 143-152. [CrossRef] [PubMed]

53. Shan, A.; Wang, J.; Shang, L.; Akhtar, M.U.; Wang, Z.; Shi, B.; Feng, X.; Shan, A. Short, symmetric-helical peptides have narrow-spectrum activity with low resistance potential and high selectivity. Biomater. Sci. 2019, 7, 2394-2409. [CrossRef]

54. Mai, J.; Tian, X.-L.; Gallant, J.W.; Merkley, N.; Biswas, Z.; Syvitski, R.; Douglas, S.E.; Ling, J.; Li, Y.-H. A Novel Target-Specific, Salt-Resistant Antimicrobial Peptide against the Cariogenic Pathogen Streptococcus mutans. Antimicrob. Agents Chemother. 2011, 55, 5205-5213. [CrossRef]

55. Salvatore, F.; Galdiero, S.; Cantisani, M.; Di Noto, R.; Vitiello, M.; Galdiero, M.; Naclerio, G.; Cassiman, J.-J.; Pedone, C.; Castaldo, G.; et al. Novel Synthetic, Salt-Resistant Analogs of Human Beta-Defensins 1 and 3 Endowed with Enhanced Antimicrobial Activity. Antimicrob. Agents Chemother. 2010, 54, 2312-2322. [CrossRef]

56. Kohanski, M.A.; Dwyer, D.J.; Hayete, B.; Lawrence, C.A.; Collins, J.J. A Common Mechanism of Cellular Death Induced by Bactericidal Antibiotics. Cell 2007, 130, 797-810. [CrossRef]

57. Mahl, C.D.; Behling, C.S.; Hackenhaar, F.S.; de Carvalho e Silva, M.N.; Putti, J.; Salomon, T.B.; Alves, S.H.; Fuentefria, A.; Benfato, M.S. Induction of ROS generation by fluconazole in Candida glabrata: Activation of antioxidant enzymes and oxidative DNA damage. Diagn. Microbiol. Infect. Dis. 2015, 82, 203-208. [CrossRef]

58. Gautam, A.; Chaudhary, K.; Singh, S.; Joshi, A.; Anand, P.; Tuknait, A.; Mathur, D.; Varshney, G.C.; Raghava, G. Hemolytik: A database of experimentally determined hemolytic and non-hemolytic peptides. Nucleic Acids Res. 2013, 42, D444-D449. [CrossRef]

59. Chen, H.-T.; Neerman, M.F.; Parrish, A.R.; Simanek, E.E. Cytotoxicity, Hemolysis, and Acute in Vivo Toxicity of Dendrimers Based on Melamine, Candidate Vehicles for Drug Delivery. J. Am. Chem. Soc. 2004, 126, 10044-10048. [CrossRef]

60. Ling, P.; Wang, M.; Chen, X.; Garland-Campbell, K. Construction and characterization of a full-length cDNA library for the wheat stripe rust pathogen (Puccinia striiformis f. sp. tritici). BMC Genom. 2007, 8, 145. [CrossRef]

61. Yang, L.F.; Gai, J.Y.; Zhu, Y.L.; Chen, G.; Wei, G.P.; Wang, C.; Liu, Q.Q. Construction and Characterization of Full-Length cDNA Library and Expressed Sequence Tags Analysis in Developing Seeds of Vegetable Soybean. Hortic. Environ. Biotechnol. 2009, 50, 51-56.

62. Saporito, P.; Mojsoska, B.; Olesen, A.L.; Jenssen, H. Antibacterial mechanisms of GN-2 derived peptides and peptoids against Escherichia coli. Biopolymers 2019, 110, e23275. [CrossRef] [PubMed]

63. Cui, H.; Zhang, C.; Li, C.; Lin, L. Antimicrobial mechanism of clove oil on Listeria monocytogenes. Food Control. 2018, 94, 140-146. [CrossRef]

64. Guangming, S.; Yang, Y.; Yuan, Q.; Shi, G.; Wu, L.; Lou, Z.; Huo, R.; Wu, H.; Borriss, R.; Gao, X. Bacillomycin D Produced by Bacillus amyloliquefaciens Is Involved in the Antagonistic Interaction with the Plant-Pathogenic Fungus Fusarium graminearum. Appl. Environ. Microbiol. 2017, 83, e01075-e01117. [CrossRef]

65. Bie, X.; Wei, D.; Yan, P.; Zhu, X.; Shan, A.; Bi, Z. Characterization of cell selectivity, physiological stability and endotoxin neutralization capabilities of $\alpha$-helix-based peptide amphiphiles. Biomaterials 2015, 52, 517-530. [CrossRef]

66. Zhu, X.; Dong, N.; Wang, Z.; Ma, Z.; Zhang, L.; Ma, Q.; Shan, A. Design of imperfectly amphipathic $\alpha$-helical antimicrobial peptides with enhanced cell selectivity. Acta Biomater. 2014, 10, 244-257. [CrossRef]

67. Maurya, I.K.; Pathak, S.; Sharma, M.; Sanwal, H.; Chaudhary, P.; Tupe, S.G.; Deshpande, M.; Chauhan, V.S.; Prasad, R. Antifungal activity of novel synthetic peptides by accumulation of reactive oxygen species (ROS) and disruption of cell wall against Candida albicans. Peptides 2011, 32, 1732-1740. [CrossRef] 
68. Dong, N.; Ma, Q.; Shan, A.; Lv, Y.; Hu, W.; Gu, Y.; Li, Y. Strand Length-Dependent Antimicrobial Activity and Membrane-Active Mechanism of Arginine- and Valine-Rich $\beta$-Hairpin-Like Antimicrobial Peptides. Antimicrob. Agents Chemother. 2012, 56, 2994-3003. [CrossRef]

69. Mares, D. Electron microscopy of Microsporum cookei after in vitro treatment with protoanemonin: A combined SEM and TEM study. Mycopathology 1989, 108, 37-46. [CrossRef]

70. Ke, Y.; Hui, S.; Yuan, M. Xanthomonas oryzae pv. oryzae Inoculation and Growth Rate on Rice by Leaf Clipping Method. Bio Protoc. 2017, 7, 2568. [CrossRef]

Publisher's Note: MDPI stays neutral with regard to jurisdictional claims in published maps and institutional affiliations.

(C) 2020 by the authors. Licensee MDPI, Basel, Switzerland. This article is an open access article distributed under the terms and conditions of the Creative Commons Attribution (CC BY) license (http://creativecommons.org/licenses/by/4.0/). 